\title{
ANNUAL REPORTS
}

\section{REPORT OF THE TREASURER FOR THE YEAR 1909}

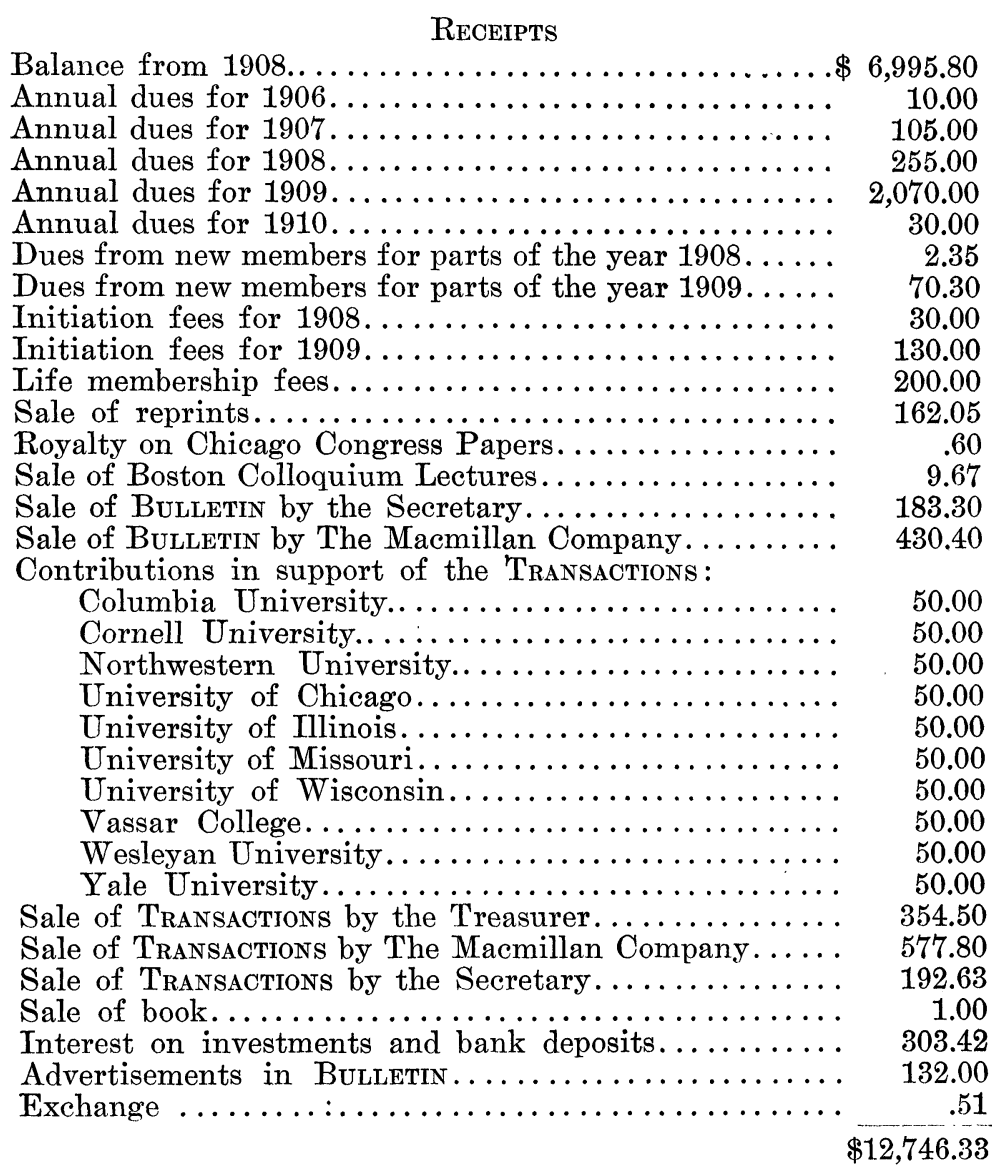

Disbursements

Expenses of the Secretary's Office.............\$ 731.02

Expenses of the Treasurer's Office................ 132.03

Expenses of the Library....................... 61.93

Expenses of the Committee of Publication.......... 107.05

Expenses of the Editorial Committee of Transactions. . 60.70 
Publication of Bulletin (eleven numbers).......... 1,567.14

Publication of Transactions (four numbers)........ 1,741.26

Annual Register......................... $18{ }_{18,89}$

Expenses of the Chicago Section................ 85.03

Expenses of the San Francisco Section............. 10.00

Expenses of the Southwestern Section............. 17.50

Insurance ............................... $\quad 39.80$

Exchange $\ldots \ldots \ldots \ldots \ldots \ldots \ldots \ldots \ldots \ldots \ldots \ldots \ldots \ldots \ldots \ldots, \quad .20$

Investments (par value, $\$ 5,500) \ldots \ldots \ldots \ldots . \$ 5,259.50$

$\$ 4,742.55$

Balance in First National Bank (Ithaca) ...... 229.23

Balance in Ithaca Savings Bank........... 1,000.00

Balance in Union Square Savings Bank...... 1,515.05

The Life Membership Fund now amounts to $\$ 3,581.70$

J. H. TANNER, Treasurer.

ITHACA, N. Y., December 18, 1909.

\section{REPORT OF THE AUDITING COMMITTEE}

The undersigned Auditing Committee, appointed by the American Mathematical Society, have this day examined the accounts of the Treasurer and find the following to be correct:

Balance from December 22, 1908.............\$ 6,959.80

Cash receipts since December 22, 1908.......... 5,786.53

Balance in First National Bank (Ithaca) ....\$ 229.23

$\$ 12, \overline{746.33}$

Balance in Ithaca Savings Bank............ 1,000.00

Balance in Union Square Savings Bank....... 1,515.05

Investments (par value, $\$ 5,500) \ldots \ldots \ldots \ldots \ldots . . \ldots, 259.50$

Disbursements since December 22, 1908. . . . . 4,742.55

$\$ 12,746.33$

LuCIEN A. WAIT, JAMES McMaHoN,

TTHACA, N. Y., December 18, 1909. Auditing Committee. 
The Librarian begs to report that the library has maintained its normal growth during the past year, the total number of volumes on the shelves having now reached nearly 3,300. The last complete catalogue of the library was published in the Annual Register of January, 1905, since which time, in the case of books other than journals, only the accessions have been indicated in the Register. In order to make the complete catalogue more accessible to the members, it has seemed desirable to issue it as a separate publication, corrected to January, 1910. This will be published and distributed to the members at an early date.

It will be seen that in the case of several important journals the library sets are incomplete. The Librarian suggests to members that any assistance which they can give in the way of completing these sets, by individual contributions, or negotiating exchanges, will be a valuable service to the Society. Gifts of mathematical books, especially of those published by our members, will be gratefully received. One of the aims of the library is to preserve a record of the growth of mathematics in this country, and to this end the cooperation of the members of the Society is solicited.

The following table shows the growth of the library during the past eight years:

\begin{tabular}{|c|c|c|c|}
\hline & $\underset{1902 .}{\text { January } 1,}$ & $\underset{1906 .}{\text { January } 1,}$ & $\underset{1910}{\text { January }} 1$, \\
\hline $\begin{array}{l}\text { Yolumes of periodicals.................. } \\
\text { Volumes, non-periodical................ } \\
\text { Periodicals on exchange list ......... }\end{array}$ & $\begin{array}{l}32 \\
89 \\
64\end{array}$ & $\begin{array}{r}1,769 \\
547 \\
164\end{array}$ & $\begin{array}{l}2,484 \\
789^{*} \\
176\end{array}$ \\
\hline
\end{tabular}

* Exclusive of unbound dissertations.

It is perhaps not generally appreciated that the library is at the service of the members of the Society, who can have the books sent to them under the rules printed in the Catalogue. Prompt attention is always given to members' requests for books. The library aims to be of real service in this direction.

David Eugene Smith, Librarian.

New YoRK, December 27, 1909. 